COMMENTARIES \& NOTES

\title{
Professor Aries Kovoor (1927 - 2006)
}

"A scientist owes much to society and his own origins"

(A. Kovoor, 1987)

Professor Aries Kovoor was born on the $3^{\text {rd }}$ of March 1927. $\mathrm{He}$ had his schooling in Jaffna and graduated from the University of Madras in 1945. He then joined the Botanical

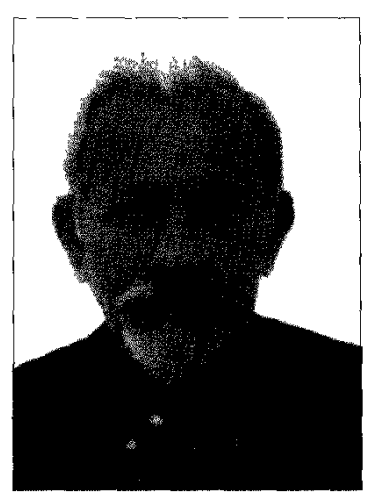

Research Laboratories of Madras University in the same year to pursue a research career. He returned to Sri Lanka and joined the staff of St. Thomas' College. Its Principal, Dr R. L. Hayman (a physiologist from Oxford University), urged him to return to a research career which made him join the Tata Institute, New Delhi which was then headed by Homi J.

Bhabha, to study the biological effects of radiations. In 1952, he entered Gautheret's laboratory at the Sorbonne University and was appointed Stagiaire de recherché of the Centre National de la Recherche Scientifique (CNRS) by the end of the year. On his career as a tenured scientist of the CNRS, he was appointed to the successive grades of Attache (1954), Charge (1960), Maitre (1968) and Directeur (1984). He closely collaborated with Gautheret for almost 18 years until 1969. With the reorganization of French Universities, he became Head of the Laboratoire de Physiologie de la Differeciation Cellulaire Vegetale of the Université Paris VIl where he held a professorial rank. He retired in 1992.

His research has contributed significantly to development of plant tissue culture, elucidation of mechanisms involved in cell proliferation, plant tumors (crown gall), recombinant DNA technology, plant molecular biology and tropical agriculture.

Prof. Kovoor has held the following positions by virtue of his professional qualifications and reputation; Elected representative of the Cell Biology section of the French Comité national de le Recherché Scientifique (1967-1971), Vice President of the Sri Lanka Rationalist Association (1970), Member of the Mouvement Universel pour la Responsibilite Scientific (France), Member of scientific and administrative councils of the Université Paris VII, and Science Advisor to H. E. the President of the Democratic Socialist Republic of Sri Lanka $(1996,2005)$.

While serving at the Universite Paris VII, he initiated research related to tissue culture of tropical plants at some of the national research institutes. The tissue culture laboratory of the Coconut Research Institute at Lunuwila was designed and developed by him and he made a significant contribution to initiating tissue culture research in coconut in Sri Lanka. He was also a visiting Professor at the Institute of Fundamental Studies (IFS), Kandy and initiated the Plant Biotechnology Project in 1988.

I first came to know Prof. Aries Kovoor in 1988 when Prof. Cyril Ponnamperuma, the then Director of the Institute of Fundamental Studies (IFS), assigned me to work in the Plant Biotechnology Project under his guidance. These were the formative years of the IFS and facilities were limited. Prof. Kovoor treated alike all persons working in the laboratory. What we achieved in the laboratory was more important to him than the degrees we held (or did not hold). He recognized our strengths and weaknesses and guided us to develop a taste for research in a very unusual manner.

The first question he asked me was "How good are you with your hands?" I proudly showed him some photomicrographs of a few specimen that I had processed. I was rather disappointed that he did not seem impressed! But he asked me to practice dissection of seeds to excise embryos under sterile conditions, which was not easy at first. From then on, I excised embryos from many species and experimented on culture media that made them germinate. This was the basis of many of the studies that were made subsequently. Juvenile rootstocks developed in this manner were used to study grafting compatibilities that led to micrografts of cashew, mangosteen and durian. Other noteworthy work initiated by Prof. Kovoor included micropropagation of giant bamboo starting with germinated embryos and Rattan embryos which gave rise to multiple plants that could be kept longer in vitro unlike their seeds with a short viability period. He enlightened 
us with new ideas that we eagerly tried out. We never had formal meetings with him but met at meal times. These conversations led to new ideas that were tried out in the lab. He discouraged too much talking about what we were "going to do" with a notice in the lab "Read, Think, Do the experiment and then Talk about it". This was his motto even after assuming duties as Science Advisor to H.E. the President. He was quiet and observant. We often accompanied him to workshops or conferences where he occupied an unobtrusive place at the back, never made any comment but listened to everything. He was a good listener and was soon able to discern problems faced by our researchers. When he became Science Advisor to H.E. the President, he already had a good understanding of the state of scientific research and its potential in our state institutes and made plans to improve it. The NRC (National Research Council) was initiated to provide grants to persons who could forward a good research proposal, without any discrimination as long as the study was original and basic. $\mathrm{He} / \mathrm{she}$ was given the freedom to use funds with the least interference. However, the grantee was responsible for funds used and to produce a good research output, which was evaluated on none other than international criteria of publication in reputed peer reviewed journals. If there were no outputs, the major equipment purchased were taken back to be used by a deserving grantee. Another scheme to improve research output was the research bonus for publications in journals in the Science Citation Index. He also believed in reducing the bonus by half for collaborative research with foreign organizations. Although certain scientists did not welcome this and argued that we have not got the facilities or the training abroad to do frontier research, it was done with the best of intentions, to encourage our researchers to develop their own skills and capabilities and be independent. "Funds will be given if asked for; you have to train your self and become capable. After all, who 'trained 'them'?" was his answer. He was concerned that our scientists were too dependent on their foreign counterparts and afraid to cut this umbilical cord, especially after foreign training in developed countries. $\mathrm{He}$ also understood that local researchers were unable to meet the costs of attending conferences in foreign countries and the research bonus was meant to be used at such times. He was able to convince the Government to increase the allocation for research funds.
He was humble, yet dignified and did not exercise authority. He preferred to drive his vehicle rather than be driven in a state vehicle or a limousine. In the early days, he used to hire a funny old car, which could even be driven with his room key! We used to accompany him often in this car that crawled to Dambulla, Kandalama and various other places of interest where he was also trying to locate a place to set up a live 'Tree Bank'. This was another of his ideas, where germplasm of all useful tropical trees were to be deposited as live collections. With this in mind he collected data about tree species. All available data were stored in a computer package named the "Tree Bank Data" that his son developed. Using this package, information on any tree species could be easily retrieved just by the click of a key. He also started a live collection at the same time. Whenever he visited a foreign country, he brought embryos of tree species cultured in vitro using a special container, the 'Sossou flasks', developed by one of his collaborators. These were further grown in our lab and the survivors were given, along with a data sheet, to a few of his friends who were willing to plant them in their gardens.

As Science Advisor to H.E. the President he did not accept a salary or an official vehicle. Much later he had to accept an official vehicle due to his failing health. He continued to be a bench worker until the unfortunate disability, at eighty years of age, which prevented his direct involvement in active research. It was his way of life, which enabled him to think so clearly until his illness.

An avid reader, he was able to acquire an immense knowledge through reading. He was well informed about research evaluation methods used in other countries and merits of the tenure track tenure method of employment followed in the United States for increasing research output.

His method was one of simplicity and precision within a framework of flexibility and transparency. He believed that heads of research institute should be bench workers active in research.

His unexpected demise after an illness was a shock to us. During the period of illness, his wife was untiringly by his side with admirable devotion. His parting on the $1^{\text {st }}$ of December 2006 saddened us. He will never be forgotten for what he inspired in many of us.

\section{Shantha Ramanayake}

Plant Biotechnology Project, Institute of Fundamental Studies, Hantana Road, Kandy 